\title{
INVESTIGATION OF G+265C AND G-1539A SINGLE NUCLEOTIDE POLYMORPHISMS OF TOLL-LIKE RECEPTOR 4 GENE (TLR4) IN SOME CATTLE BREEDS RAISED IN TURKEY
}

\author{
Özgecan Korkmaz Ağaoğlu*, Bilal Akyüz², Emel Zeytünlü̉ ${ }^{3}$ Ali Reha Ağaoğlu \\ ${ }^{1}$ Department of Animal Science, ${ }^{4}$ Department of Obstetrics and Gynecology, Faculty of Veterinary Medicine, Burdur Mehmet Akif Ersoy \\ University, Burdur, 15030, ${ }^{3}$ Department of Animal Science, Institute of Health Sciences Burdur Mehmet Akif Ersoy University, Burdur, 15030 , \\ ${ }^{2}$ Department of Genetics, Faculty of Veterinary Medicine, Erciyes University, Kayseri, 38039, Turkey \\ *Corresponding author, E-mail: ozgecanagaoglu@mehmetakif.edu.tr
}

\begin{abstract}
Toll-like receptors play an essential role in how the innate immune system reacts to pathogens. These receptors help the innate immune system recognise the antigenic structure of pathogens and initiate the inflammatory response. TLR4 is one of these receptors, and it has been identified as a candidate molecular marker for resistance to mastitis in cattle. This study aimed to describe G-1539A (Bgll) in promoter and G+265C (Mspl) in 5'-UTR polymorphisms in the TLR4 gene using Zavot ( $n=60$ ), East Anatolian Red (EAR, $n=49$ ), Anatolian Black (AB, n=59), South Anatolian Red (SAR, $n=42$ ), Turkish Gray (TG, $n=60$ ) and Holstein $(n=218)$ cattle breeds. For this purpose, we used polymerase chain reaction and restriction fragment length polymorphism (PCR-RFLP) to genotype a total of 488 cattle. Two alleles ( $A$ and $G$ ) and three genotypes (GG, GA and AA) were examined by digestion of the PCR product with Bgll restriction enzyme. The frequency of the $G$ allele was higher in all investigated breeds except Zavot. The GA genotype was found to be the most common genotype in the EAR, SAR, TG, AB, Holstein, and Zavot breeds. Two alleles ( $C$ and $G$ ) and three genotypes ( $G G, G C$ and $C C$ ) were examined by digestion of the PCR product for the $\mathrm{G}+265 \mathrm{C}$ SNP with the Mspl restriction enzyme. The most prevalent in terms of frequency was the Callele in all breeds with regard to $G+265 C$ SNP. All examined breeds were within the Hardy-Weinberg equilibrium ( $p>0.05$ ). Consequently, the existence of two SNPs of the TLR4 gene has been reported for the first time in six cattle breeds raised in Turkey. The study demonstrated that the investigated breeds continue to exhibit variation in terms of these two SNPs. It might be possible to utilise these polymorphisms in efforts to breed herds resistant to significant breeding diseases, such as mastitis.
\end{abstract}

Key words: cattle; PCR-RFLP; promoter; SNP;TLR4

\section{Introduction}

As an effect of antagonistic genetic correlations between milk yield and immunity, a decline in resistance to disease has been observed in highly productive herds $(1,2)$. The goal of high profitability has complicated the issue of selecting the most appropriate method for production as well as fertility management, udder health, and resistance to disease while maximising profit without compromising animal welfare. Recent

Received: 17 June 2019

Accepted for publication: 10 January 2020 studies have shown that creating herds resistant to serious breeding diseases, such as mastitis, tuberculosis, and brucellosis, could increase the profitability of livestock enterprises $(3,4)$. However, creating healthy herds with genetic improvement programmes in dairy populations takes a long time. Nowadays, it is thought that some genes, such as toll-like receptor genes, could be used to increase immune resistance in livestock.

In mammals, the immune system is divided into the innate and adaptive immune systems. Toll-like receptors (TLRs), an essential component of the immune system, activate innate immune reactions, which then cause adaptive immune 
responses $(5,6)$. The genes coding the proteins involved in TLRs belong to an ancient gene family that is found in vertebrates, invertebrates, and even plants (7). In mammals, the TLR family plays a crucial role in the recognition of pathogenassociated molecular patterns (PAMPs) in the proteins of pathogenic organisms (8).

The mucosal defence is the most critical part of the innate immune system. Mucosal barriers are the initial line of protection against antigens. They play a critical role in preventing infections. One part of this preventative function is a class of cell surface receptors called 'pattern recognition receptors' (PRRs), which recognise specific PAMPs on bacteria (9). TLRs are the best-known members of the PRR family. After PAMP recognition by TLRs, the innate immune response genes are induced via activation of cellular signalling pathways, including inflammatory cytokines (6). In mammals, there are thirteen members of the TLR family, and each member recognises specific PAMPs (10). Some of the TLRs are located on the cell surface, whereas some parts are intracellular (11). TLR4 is a cell surface receptor that recognises the broad class of PAMPs, and it plays a crucial role in pathogen defence through the activation of innate and adaptive immunity, especially against endotoxins of gram-negative bacteria $(9,12,13,14)$.

TLR4 has an especially important role in the immune recognition of mycobacteria that cause significant breeding diseases $(15,16)$. The TLR4 gene was mapped in Bos taurus chromosome 8 (17). Some mutations in the TLR4 gene may reduce the immune response to microbial cell wall components, including lipopeptides and lipopolysaccharide $(15,16,18)$. Due to its role in the development of immunity against bacteria, it has been suggested that the TLR4 gene is a potential candidate gene for resistant-to-breeding diseases, such as mastitis, tuberculosis, brucellosis, paratuberculosis, etc. $(10,19,20,21,22)$.

A healthy mucosal epithelium and heathly PRRs are the first lines of defence against bacteria in the development of mastitis in the mammary gland $(12,23)$. Differences in the TLR4 gene expression profile in the mammary gland are associated with mastitis in dairy cattle (23). In this regard, several studies have shown a relationship between TLR4 gene polymorphism and mastitis, somatic cell score (SCS) and lactation persistency in cattle $(12,19,24,25)$. These data demonstrate the importance of polymorphisms in the TLR4 gene and indicate it could serve as a molecular marker for mastitis sensitivity, and might be used in marker-assisted selection (MAS) programmes in dairy herds (19).

Turkey has several native cattle breeds, which are significant not only in terms of genetic resources but also in terms of yields and are described as follows: The Anatolian Black (AB) breed is raised in a broad area in the middle of Turkey for meat. The East Anatolian Red (EAR) breed is reared mostly in Northeast Anatolia primarily for meat, but there is also some milk production. The Turkish Gray (TG) breed is raised in the northwest region of Turkey, again primarily for meat but it is also used for milk production. The South Anatolian Red (SAR) breed is bred in South Anatolia, but it is also raised in Iraq, Syria, Lebanon, and Jordan. It is bred primarily for milk production. The Zavot breed is raised in Northeast Anatolia. It is a hybrid created by crossing Brown Swiss, Simmental, and EAR. It is reared primarily for meat yield. In this context, the objective of the present study was to identify Single Nucleotide Polymorphisms (SNPs) within the TLR4 gene in some Turkish native cattle breeds (Zavot, EAR, AB, SAR, and TG) and Holsteins raised in Turkey.

\section{Materials and methods}

\section{Sampling and DNA Extraction}

Blood samples were collected from 488 cows, using the tail vein, and placed in sterile vacuumed tubes containing K3 EDTA. They were stored at $-20^{\circ} \mathrm{C}$ until analysis. A total of 488 blood samples were examined from different breeds such as Zavot ( $n=60$, Ardahan), AB ( $n=59$, Ankara and Çankırı), SAR ( $n=42$, Şanlıurfa and Adana), TG ( $n=60$, Edirne and Balikesir), EAR ( $n=49$, Erzurum and Kars) and Holstein ( $\mathrm{n}=218$, Burdur). The extraction of genomic DNA was performed using phenol:chloroform:isoamyl alcohol (25:24:1) and a DNA extraction kit (GeneJET Genomic DNA Purification Kit). Genomic DNA samples were analysed using NanoDrop 2000 (Thermo Scientific) for quantity and quality controls.

This study was approved by the Local Ethics Committees on Animal Experiments at Mehmet Akif Ersoy University (approval no: 03.12.2012/07) and Erciyes University (approval no: $11.12 .2013 / 157)$. 
Table 1: Primer sequence, PCR product size, primer annealing temperature (Ta) and Restriction Endonucleases (RE) (26)

\begin{tabular}{|c|c|c|c|c|c|}
\hline SNPs & Primer (5'-3') Forward, Reverse & PCR & $\mathrm{Ta}$ & $\mathrm{RE}$ & RFLP Profile \\
\hline $\begin{array}{c}\text { SNP1 } \\
(\mathrm{G}-1539 \mathrm{~A})\end{array}$ & $\begin{array}{l}\text { 5'-TTC TTC AAC CCA ACC CAC CT-3' } \\
\text { 5'-GCC CTG GCT CAC CAC AAC TA-3' }\end{array}$ & $546 b p$ & $59.1^{\circ} \mathrm{C}$ & $B g I I$ & $\begin{array}{c}\text { AA: } 546 \\
\text { GG: } 423+123 \\
\text { GA: } 546+423+123\end{array}$ \\
\hline $\begin{array}{c}\text { SNP2 } \\
(\mathrm{G}+265 \mathrm{C})\end{array}$ & $\begin{array}{l}\text { 5`-GGG TAT TTT GTT ATG GCT GG-3‘ } \\
\text { 5‘-CCA TCA TCC TGG CAT TTT-3‘ }\end{array}$ & $477 \mathrm{bp}$ & $54.5^{\circ} \mathrm{C}$ & $M s p I$ & $\begin{array}{c}\text { GG: } 370+65+42 \\
\text { CC: } 245+125+65+42 \\
\text { GC: } 370+245+125+65+42\end{array}$ \\
\hline
\end{tabular}

\section{Polymorphism Detection and Genotyping}

PCR was performed on a total volume of $25 \mu \mathrm{L}$ consisting of $\mathrm{MgCl}_{2}$ (2 $\mathrm{mM}$ for SNP1 and $2.5 \mathrm{mM}$ for SNP2), dNTP (200 $\mu \mathrm{M})$, primers (5 pmol) (Table 1), $1 \mathrm{X}$ buffer, Taq DNA polymerase $(1 \mathrm{U} / \mu \mathrm{L})$, and DNA ( 100 ng). Under PCR conditions, there is an initial denaturing step at $95^{\circ} \mathrm{C}$ for $5 \mathrm{~min}$, followed by 35 cycles at $94^{\circ} \mathrm{C}$ for $30 \mathrm{sec}$. for SNP1 and 32 cycles at $94^{\circ} \mathrm{C}$ for $30 \mathrm{~s}$ for SNP2, $59.1^{\circ} \mathrm{C}$ for $30 \mathrm{~s}$ for SNP1 and $54.5^{\circ} \mathrm{C}$ for $35 \mathrm{~s}$ for SNP2, and $72^{\circ} \mathrm{C}$ for $45 \mathrm{~s}$ for SNP1 and for $30 \mathrm{~s}$ for SNP2, with the last cycle at $72^{\circ} \mathrm{C}$ for $10 \mathrm{~min}$. PCR reactions were performed using the Amplitronyx Series 6 thermal cycler, and amplification products were electrophoresed on $2 \%$ agarose gel stained with ethidium bromide. In PCR products, the TLR4 gene was obtained using fast digestive enzymes (Table 1) in accordance with the manufacturer's instructions (Fermentas, Vilnius, Lithuania). The products were electrophoresed on 3\% (SNP1) and $4 \%$ (SNP2) agarose gel, after which they were imaged using an UV-transilluminator.

\section{Statistical Analysis}

Direct calculation was used to predict genetic variants of the TLR4 gene, allele frequencies, and genotype. A chi-square statistic was used to examine whether or not populations were in HWE; other statistical checks were performed using PopGene32 software (27).

\section{Results}

In this study, two alleles (A and $G$ ) and three genotypes (GG, GA and AA) were examined by digestion of PCR amplification products with the BgII restriction enzyme (Figure 1). Allelic frequency values for Zavot, AB, SAR, TG, EAR and Holstein breeds were identified as $0.44,0.53$, $0.52,0.57,0.52$, and 0.68 , respectively, for the $G$ allele, and $0.56,0.47,0.48,0.43,0.48$, and 0.32 , respectively, for the A allele. The GA genotype was the most common genotype in the Zavot, $A B$, SAR, TG, EAR, and Holstein breeds. All examined breeds were in HWE for TLR4 G-1539A polymorphisms $(p>0.05)$.

Two alleles (C and $\mathrm{G})$ and three genotypes (GG, GC and CC) were examined by digestion of PCR amplification products with Mspl restriction enzyme (Figure 2). Allelic frequency values for EAR, SAR, TG, AB, Zavot and Holstein breeds were identified as $0.12,0.06,0.29,0.31,0.15$, and 0.56 ; respectively for the $\mathrm{G}$ allele, and 0.88 , $0.94,0.71,0.69,0.85$, and 0.44 , respectively for the $\mathrm{C}$ allele. All examined breeds were in HWE for TLR4 G+265C polymorphisms ( $\mathrm{p}>0.05$ ).

\section{Discussion}

Earlier studies suggested an interaction between TLR gene polymorphisms and greater susceptibility to bacterial infections in different tissues and in different animals $(10,28,29)$. It was reported that TLR4 plays a crucial role in the host defence mechanism against gram-negative bacterial and viral agents (30).

It has also been reported that there could be a relationship between TLR4 gene polymorphism and many significant diseases, such as mastitis, brucellosis, and paratuberculosis in cattle $(10$, $22,26,29)$. Therefore, it is essential to investigate TLR4 gene polymorphism in indigenous cattle breeds. Because indigenous cattle breeds are specific examples of the bovine species, the genetic polymorphism of G+265C and G-1539A SNPs of the TLR4 gene in five Turkish native (EAR, SAR, $\mathrm{TG}, \mathrm{AB}$, and Zavot) cattle breeds were investigated. These SNPs are located in the promoter region of the TLR4 gene, and genotypes were detected using 


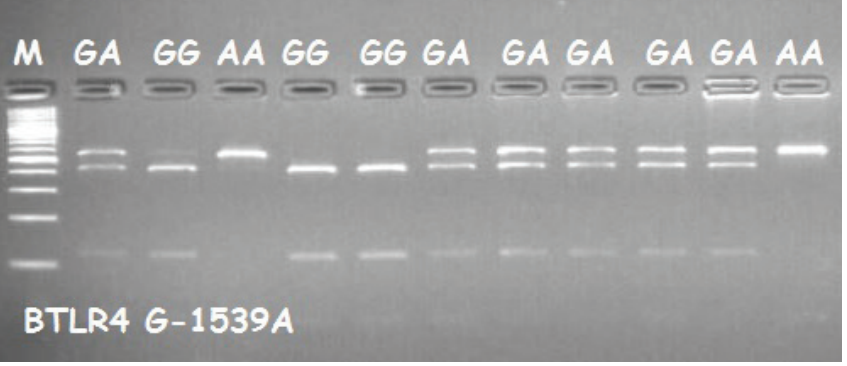

Figure 1: Agarose gel images for TLR4 G-1539A polymorphisms. Line M: $100 \mathrm{bp}$ ladder

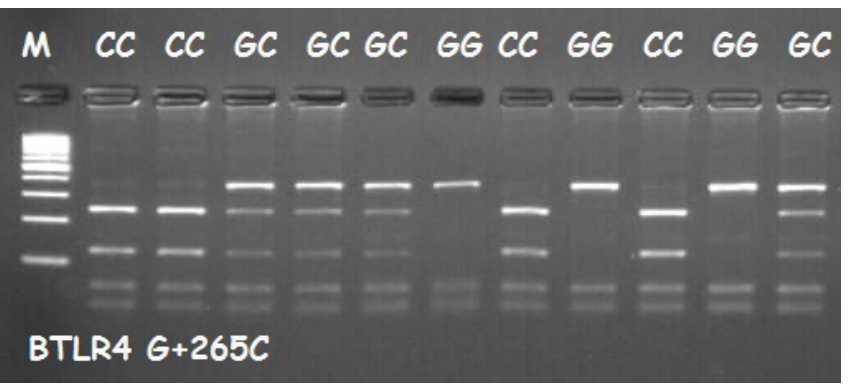

Figure 2: Agarose gel images for the TLR4 G+265C polymorphisms. Line M: 100 bp ladder

Table 2: Genotype and allele frequencies of the G-1539A (SNP1) single nucleotide polymorphism in some cattle breeds raised in Turkey

\begin{tabular}{c|c|c|c|c|c|c|c|c|c|c}
\hline \multirow{2}{*}{ Breed } & \multirow{2}{*}{$\mathrm{n}$} & \multicolumn{2}{|c|}{ Allele F. } & \multicolumn{3}{|c|}{ Genotype F. (\%) } & \multicolumn{2}{c|}{ Heterozygosity } & \multirow{2}{*}{ Ne } & \multirow{2}{*}{$\chi^{2}(\mathrm{df}=1)$} \\
\cline { 3 - 10 } EAR & 49 & 0.52 & 0.48 & 28.6 & 46.9 & 24.5 & 0.47 & 0.50 & 1.99 & 0.24 Ns \\
\hline SAR & 42 & 0.52 & 0.48 & 23.8 & 57.1 & 19.1 & 0.57 & 0.50 & 1.99 & $0.75^{\text {NS }}$ \\
\hline TG & 60 & 0.57 & 0.43 & 28.3 & 56.7 & 15.0 & 0.56 & 0.49 & 1.97 & 1.27 NS \\
\hline AB & 59 & 0.53 & 0.47 & 25.4 & 55.9 & 18.7 & 0.56 & 0.50 & 1.99 & 0.78 Ns \\
\hline Holstein & 218 & 0.68 & 0.32 & 44.9 & 45.9 & 9.2 & 0.46 & 0.44 & 1.77 & 0.54 Ns \\
\hline Zavot & 60 & 0.44 & 0.56 & 16.7 & 55.0 & 28.3 & 0.55 & 0.50 & 1.97 & 0.68 Ns \\
\hline
\end{tabular}

F.: Frequency, Ne: effective number of alleles, NS: Nonsignificant

Table 3: Genotype and allele frequencies of the G+265C (SNP2) single nucleotide polymorphism in some cattle breeds raised in Turkey

\begin{tabular}{|c|c|c|c|c|c|c|c|c|c|c|}
\hline \multirow{2}{*}{ Breed } & \multirow{2}{*}{$\mathrm{n}$} & \multicolumn{2}{|c|}{ Allele F. } & \multicolumn{3}{|c|}{ Genotype F. (\%) } & \multicolumn{2}{|c|}{ Heterozygosity } & \multirow{2}{*}{$\mathrm{Ne}$} & \multirow{2}{*}{$\chi^{2}(\mathrm{df}=1)$} \\
\hline & & $\mathrm{G}$ & $\mathrm{C}$ & GG & GC & $\mathrm{CC}$ & Ho & $\mathrm{He}$ & & \\
\hline EAR & 49 & 0.12 & 0.88 & 2.0 & 20.4 & 77.6 & 0.20 & 0.22 & 1.27 & $0.19^{\mathrm{NS}}$ \\
\hline SAR & 42 & 0.06 & 0.94 & 0.0 & 11.9 & 88.1 & 0.12 & 0.11 & 1.13 & $0.13^{\mathrm{NS}}$ \\
\hline TG & 60 & 0.29 & 0.71 & 8.3 & 41.7 & 50.0 & 0.42 & 0.42 & 1.70 & 0.00 NS \\
\hline $\mathrm{AB}$ & 59 & 0.31 & 0.69 & 8.4 & 45.8 & 45.8 & 0.46 & 0.43 & 1.76 & $0.18^{\mathrm{NS}}$ \\
\hline Holstein & 218 & 0.56 & 0.44 & 30.3 & 51.4 & 18.3 & 0.51 & 0.49 & 1.97 & 0.35 Ns \\
\hline Zavot & 60 & 0.15 & 0.85 & 0.0 & 30.0 & 70.0 & 0.30 & 0.26 & 1.34 & $1.75^{\mathrm{NS}}$ \\
\hline
\end{tabular}

F: Frequency, Ne: effective number of alleles, NS: Nonsignificant 
PCR-RFLP analysis. These polymorphisms were first reported in Chinese Holsteins, and these polymorphisms could potentially be used as a candidate for the application of molecular markerassisted selection programmes in Holstein cattle by Li et al. (26).

Li et al. (26) genotyped G+265C and G-1539A polymorphisms in 421 Chinese Holstein cattle, and they identified all three genotypes with different frequencies of two SNPs. At locus G-1539A, which is in the promoter region of the TLR4 gene, the GG genotype frequency was higher $(52 \%)$ than other genotype frequencies. However, the GA genotype frequency value was higher than other genotypes in five Turkish domestic cattle breeds examined in our study. However, among the cattle breeds examined, the GG genotype frequency (44.9\%) was highest in Holstein cattle bred in Turkey. It was also close to the GA genotype frequency (45.9\%). An association analysis was performed between the TLR4/G-1539A/BgII polymorphism and 305-day milk yield in Chinese Holstein cattle, and a significant association was detected between 305-day milk yield and the GG genotype. However, the homozygote GG genotype frequency was lower than the GA genotype in all examined cattle breeds. Nevertheless, the five native cattle breeds showed that GA genotype is more frequent than the other two genotype (GG and AA) groups. However, the observed genetic variation continues in the six cattle breeds examined in Turkey. In the light of these results, it can be speculated that increasing the genotype frequency value of the GG genotype at the TLR4/G-1539A locus may be responsible for increasing milk yield in Holstein cattle in Turkey and Turkish native cattle.

For the TLR4/G+265C site, Li et al. (26) found that the frequency of other genotypes in the Chinese Holstein population was lower than the GC genotype. Similar to our results, the GC genotype frequency $(51.4 \%)$ was higher than other genotypes in the Holstein population raised in Turkey. For this polymorphism, unlike the Holstein breed, we found that the frequency of other genotypes in the five examined Turkish native cattle breeds was lower than the $\mathrm{CC}$ genotype. All breeds in the current demonstrated Hardy-Weinberg equilibrium for two SNPs at the TLR4 gene.

Li et al. (26) genotyped this SNP in Chinese Holsteins, and they reported an association between TLR4/G+265C polymorphism and SCS in the examined Holstein population. A previously conducted study reported that it could be a correlation between another SNP named T4CRBR1 in the TLR4 gene and SCS and mastitis in Chinese Holstein cattle (12). They also reported that this correlation was not found in Simmental and Sanhe cattle breeds (12). Another study by this group of researchers found a new SNP, which was an association with SCS in Holstein, Simmental and Sanhe cattle breeds (29). Another study found a relationship between an SNP in the TLR4 gene and bovine brucellosis (22). These investigations show that SNPs in the TLR gene could be used to increase disease resistance in cattle.

The data from this study has demonstrated that TLR4 polymorphisms exist in both Holstein cattle breeds and all indigenous cattle breeds raised in Turkey. Maintaining the variation in the gene pool is essential for genotyping cattle breeds and is a criterion for selection against various infections and development of yield traits in cattle. Further research should be conducted to investigate the relationship between resistance to important breeding diseases, such as mastitis, and yield traits in commonly raised cattle breeds, such as Holstein and native cattle breeds.

\section{Acknowledgements}

This study was presented in the $6^{\text {th }}$ National Veterinary Animal Science Congress, 1-4 June 2016, Cappadocia, Turkey.

\section{References}

1. Jones WP, Hansen LB, Chester-Jones H. Response of health care to selection for milk yield of dairy cattle. J Dairy Sci 1994; 77: 3137-52.

2. Lucy MC. Reproductive loss in high-producing dairy cattle: where will it end? J Dairy Sci 2001; 84: 277-93.

3. Egger-Danner C, Willam A, Fuerst C, Schwarzenbacher H, Fuerst-Waltl B. Hot topic: effect of breeding strategies using genomic information on fitness and health. J Dairy Sci 2012; 95: 4600-9.

4. Parker Gaddis KL, Cole JB, Clay JS, Maltecca C. Genomic selection for producer-recorded health event data in US dairy cattle. J Dairy Sci 2014; 97: 3190-9.

5. Takeda K, Akira S. Roles of toll-like recep- 
tors in innate immune responses. Genes Cells 2001; 6: 733-42.

6. Takeda K, Kaisho T, Akira S. Toll-like receptors. Annu Rev. Immunol 2003; 21: 335-376.

7. Kaisho T, Akira S. Toll-like receptor function and signaling. J Allergy Clin Immunol 2006; 117: 979-87.

8. Medzhitov R, Janeway C. Innate immunity. N Engl J Med 2000; 343: 338-44.

9. Akira S, Hemmi H. Recognition of pathogen-associated molecular patterns by TLR family. Immunol Lett 2003; 85: 85-95.

10. Mucha R, Bhide MR, Chakurkar EB, Novak M, Mikula IS. Toll-like receptors TLR1, TLR2 and TLR4 gene mutations and natural resistance to Mycobacterium avium subsp. paratuberculosis infection in cattle. Vet Immunol Immunopathol 2009; 128: 381-8.

11. Coll RC, O'Neill LA. New insights into the regulation of signaling by Toll-like receptors and Nodlike receptors. J Innate Immun 2010; 2: 406-21.

12. Wang X, Xu S, Gao X, Ren H, Chen J. Genetic polymorphism of TLR4 gene and correlation with mastitis in cattle. J Genet Genomics 2007; 34(5): 406-12.

13. Akira S, Takeda K, Kaisho T. Toll-like receptors: critical proteins linking innate and acquired immunity. Nat Immun 2001; 2(8): 675-80.

14. Akira S, Takeda KT. Toll-like receptor signaling. Nat Rev Immunol 2004; 4(7): 499-511.

15. Hawn TR, Misch EA, Dunstan, SJ, et al. A common human TLR1 polymorphism regulates the innate immune response to lipopeptides. Eur J Immunol 2007; 37(8): 2280-9.

16. Omueti KO, Mazur DJ, Thompson KS, Lyle EA, Tapping RI. The polymorphism P315L of human Toll-like receptor 1 impairs innate immune sensing of microbial cell wall components. J Immunol 2007; 178: 6387-94.

17. White SN, Kata SR, Womack JE. Comparative fine maps of bovine toll-like receptor 4 and toll-like receptor 2 regions. Mamm Genome 2003; 14(2): 149-55.

18. Schwartz DA. The genetics of innate immunity. Chest 2002; 121: 62S-8S.

19. Sharma BS, Leyva I, Schenkel F, Karrow NA. Association of toll-like receptor 4 polymorphisms with somatic cell score and lactation persistency in Holstein bulls. J Dairy Sci 2006; 89(9): 3626-35.

20. Pinedo PJ, Buergelt CD, Donovan GA, et al. Candidate gene polymorphisms (BoIFNG, TLR4,
SLC11A1) as risk factors for paratuberculosis infection in cattle. Prev Vet Med 2009; 91(2/4): 189-96.

21. Pulido I, Leal M, Genebat M, Pacheco YM, Sáez ME, Soriano-Sarabia N. The TLR4 ASP299GLY polymorphism is a risk factor for active tuberculosis in Caucasian HIV-infected patients. Curr HIV Res 2010; 8(3): 253-8.

22. Prakash O, Kumar A, Sonwane A, et al. Polymorphism of cytokine and innate immunity genes associated with bovine brucellosis in cattle. Mol Biol Rep 2014; 41(5): 2815-25.

23. Goldammer T, Zerbe H, Molenaar A, et al. Mastitis increases mammary mRNA abundance of a-defensin 5, toll-like receptor 2 (TLR2), and TLR4 but not TLR9 in cattle. Clin Vaccine Immunol 2004; 11: 174-85.

24. Zhang LP, Gan QF, Ma TH, et al. Toll-like receptor 2 gene polymorphism and its relationship with SCS in dairy cattle. Anim Biotechnol 2009; 20(3): 87-95.

25. Yuan Z R, Li J, Zhang, LP, et al. Novel SNPs polymorphism of bovine CACNA2D1 gene and their association with somatic cell score. Afr J Biotechnol 2011; 10(10): 1789-93.

26. Li $Z$, Zhang $\mathrm{H}$, Wang $\mathrm{H}$, et al. Polymorphism in the promoter of TLR4 gene by PCR-RFLP and its association with somatic cell score in Chinese Holstein. Arch Tierzucht 2014; 57(6):1-6.

27. Yeh FC, Yang RC, Boyle T. POPGENE version 1.32: Microsoft Windows-based freeware for population genetic analysis. Edmonton, Alberta, Canada : Center for International Forestry Research, University of Alberta, 2000.

28. Rezazadeh M, Hajilooi M, Rafiei A, et al. TLR4 polymorphism in Iranian patients with brucellosis. J Infect 2006; 53(3): 206-10.

29. Wang XP, Xu SZ, Gao X, Li JY. Cloning and SNP screening of the TLR4 gene and the association between its polymorphism and somatic cell score in dairy cattle. S Afr J Anim Sci 2008; 38(2): 101-9.

30. Mariotti M, Williams JL, Dunner S, et al. Polymorphisms within the toll-like receptor (TLR)$2,-4$, and -6 genes in cattle. Diversity 2009; 1 : $7-18$. 


\title{
RAZISKOVANJE ENOJNIH NUKLEOTIDNIH POLIMORFIZMOV G+265C IN G-1539A GENA RECEPTORJA TLR4 PRI NEKATERIH PASMAH KRAV, GOJENIH V TURČIJI
}

\author{
Ö. Korkmaz Ağaoğlu, B. Akyüz, E. Zeytünlü, A. R. Ağaoğlu
}

Povzetek: Tolični receptorji oz. receptorji TLR (iz angl. Toll-like receptors) igrajo bistveno vlogo pri reakciji prirojenega imunskega sistema na patogene. Ti receptorji pomagajo prirojenemu imunskemu sistemu prepoznati antigensko strukturo patogenov in sprožiti vnetni odziv. TLR4 je bil izmed skupine toličnih receptorjev prepoznan kot kandidatni molekularni označevalec za odpornost na mastitis pri govedu. V študiji smo želeli opisati G-1539A (Bgll) v promotorju in G+265C (Mspl) v 5'-UTR polimorfizmih gena TLR4 pri različnih pasmah goveda: pasmi Zavot $(n=60)$, vzhodno anatolskem rdečem govedu ( $E A R, n=49)$, anatolijskemu črnemu govedu ( $A B, n=59$ ), južno anatolskemu rdečemua govedu ( $S A R, n=42)$, turškem sivem govedu ( $T G, n=60)$ in govedu pasme Holstein ( $n=218$ ). V ta namen smo uporabili verižno reakcijo s polimerazo in polimorfizem dolžin restrikcijskih odsekov (PCR-RFLP) za genotipizacijo 488 govedi. Z restrikcijsko cepitvijo produktov PCR z restrikcijskim encimom Bgll smo pregledali dva alela (A in $G$ ) in tri genotipe (GG, GA in AA). Pogostost alela $G$ je bila večja pri vseh raziskanih pasmah, razen pasmi Zavot. Ugotovljeno je bilo, da je genotip GA najpogostejši genotip pri pasmah goveda EAR, SAR, TG, AB, Holstein in Zavot. Dva alela (C in $G$ ) in trije genotipi (GG, GC in CC) so bili pregledani z restrikcijsko cepitvijo produkta PCR za SNP G+65C z restrikcijskim encimom Mspl. Alel C je bil najbolj razširjen pri vseh pasmah. Vse pregledane pasme so bile znotraj Hardy-Weinbergovega ravnotežja $(p>0,05)$. V raziskavo torej poročamo prvič o obstoju dveh SNP gena TLR4 pri šestih pasmah govedi, vzrejenih v Turčiji. Študija je pokazala, da so pri preiskanih pasmah vidne razlike v teh dveh SNP. Te polimorfizme bi bilo mogoče uporabiti pri prizadevanjuzavzrejo čred, odpornih na pomembne bolezni pri govedu, kot je mastitis.

Ključne besede: govedo; PCR-RFLP; promotor; SNP;TLR4 